\title{
A Survey of Translation of Robert Burns’ “A Red, Red Rose” in China
}

\author{
LI Zheng-shuan \\ School of Foreign Languages, Hebei Normal University, Shijiazhuang, China
}

\begin{abstract}
Robert Burns wrote about 700 poems and songs. But the first poem that was translated into Chinese is “A Red, Red Rose”. It was collected into a book compiled in 1908 which was published in 1911. It was retranslated many times at different times, mostly by people who were both poets and translators at the same time. And almost all the translators were famous poets such as Su Manshu, Yuan Shuipai, Wang Zuoliang, Yuan Kejia, and Guo Moruo. These translators had their own unique taste and typical features. This article will present a survey of translation history and at the same time give some comments on different versions.
\end{abstract}

Keywords: Robert Burns, “A Red, Red Rose”, translation into Chinese

\section{Introduction}

Robert Burns was first introduced by Lu Xun (1881-1936) in 1908 when he mentioned Robert Burns briefly in his book On the Power of Romantic Poetry in which he talked about eight European romantic poets.

Lu Xun spoke highly of Burns in this book:

In the 18th century... in the literary circle, there was a farmer called Burns who was born in Scotland. He spared no effort to rise against the society, publicizing the concept of equality to the masses, not fearing authority, not worshipping money, showing his warmth, writing versed poems. (LU, 1980, p. 99)

Ever since then, different versions of Burns' "A Red, Red Rose” appeared in the following years such as 1944, 1959 and other years.

This article will trace the travel of this poem in China.

\section{Su Manshu’s Translation of Burns' “A Red, Red Rose”, the First Achievement Introducing a Fresh Image of Love Into Chinese Translation Literature}

Su Manshu (1884-1918) was a poet, novelist, painter, translator and a monk for a short time.

He was born in Japan into a family of a Guangdong tea merchant who fathered him with a Japanese girl with no marriage. So he grew up in Japan and Guangdong between which he shuttled in his short life.

Beginning from 1903 he worked on many posts as a teacher, editor and translator. He translated Byron, Shelley, Hugo and others, but translated only one poem of Robert Burns, i.e. “A Red, Red Rose” and collected it into his collection of poems entitled The Sound of Tides (潮音) in 1908, which was published in 1911 in Japan. Here is Su Manshu's translation of Burns' “A Red, Red Rose”:

LI Zheng-shuan, Ph.D., Professor, School of Foreign Languages, Hebei Normal University. 


\author{
熲穎赤蓄靡 \\ 熲熲赤蓄靡, \\ 首夏初发苞。 \\ 恻恻清商曲, \\ 眇音何远遥。 \\ 予美凉天绍， \\ 幽情申自持。 \\ 仓海会流枯, \\ 相爱无绝期。 \\ 仓海会流枯, \\ 顽石烂炎喜。 \\ 微命属如缕, \\ 相爱无绝期。 \\ 掺怯别予美, \\ 离隔在须里。 \\ 阿阳早日归, \\ 万里莫踟䠧。(LIU, 2007, p. 127)
}

His translation is rectified in form, in ancient style of five-character-line quatrain. The rhyme schemes of the four stanzas are respectively abab (Burns’ being abcb), abcb (Burns’ being abcb), abcb (Burns’ being abab), abab (Burns' being abab) (“头” is near rhyme with “踞” because in the south these words are pronounced in almost the same way). The language is quite literary. But this is the first time that Burns was translated into Chinese and was introduced to China. So Su Manshu must be remembered.

The language he used is archaic and abstruse, especially in diction, similar to that used in the Book of Songs, Yuefu Poetry and the poetry in the Tang Dynasty. It is quite proper that he used such language because the new culture movement would come ten years later.

It is mainly written language with occasional use of colloquial vocabulary such as "A Yang" which betrays the origin of the poet as a southerner.

The tone conveyed in the translation is sincere, warm and melancholy at the same time, which can be seen in the use of repetition of words such as “熲熲” and “恻恻”.

However, in terms of translation, it is not very faithful to the source text. For example, in the first line “熲 熲赤蓄靡”, the original simile is lost. If we translate “熲熲赤蓄靡” back into English, it is “Red, red is the rose”. Or in normal order it is "The rose is red, red”. Burns' original meaning is "The girl I love is like a red, red rose”, not that the “The rose is red”. The third line “恻恻清商曲” is not faithful, either, which means “The music is sad, sad” which is far from the intended meaning of Burns' line "O, my luve is like the melody”. There are more examples of unfaithfulness.

Su Manshu adopted the domestication strategy completely. He almost rewrote the poem based on that of Burns'. The style of the source text's outburst of enthusiasm is lost. In the translation it is more melancholy, unfaithful to the style of the source text. He overused his subjectivity and displayed his own talent, merely 
borrowing Burns' artistic conception.

But we must admit that it is Su Manshu who made the greatest contribution to spreading Burns' poetry in China as he was the first person to translate Burns. He triggered other people to translate Burns.

\section{Yuan Shuipai: The Second Person to Translate Burns’ “A Red, Red Rose” Introducing the Rose in Ordinary Language}

Yuan Shuipai (1916-1982), Yuan Guangmei by birth, a native of Jiangsu, was a poet, editor, revolutionary and a high-ranking official. He wrote political satires using the penname of Ma Fantuo and folk songs using the penname of Yuan Shuipai.

He attended a university in Shanghai in 1934 but he did not graduate. After 1937, he worked in Hong Kong and Chongqing. After 1945, he worked in Shanghai. After 1949, he worked in Beijing. After 1974, he was chosen to join other famous translators to translate Mao Zedong's poems into English. In 1976, he became vice-minister of the Ministry of Culture and then his work was stopped when the "Gang of Four" was overthrown.

He published 11 books of translation of foreign poems and translated two novels. His greatest contribution to English literature is his translation of Burns' poems collected in My Heart's in the Highlands comprised of 30 of Burns' poems and the poems of Housman, published in 1944 in Chongqing by Xinqun Press when he was only 28. "A Red, Red Rose” is one of the poems translated. Here is Yuan Shuipai's translation of Burns' “A Red, Red Rose”:

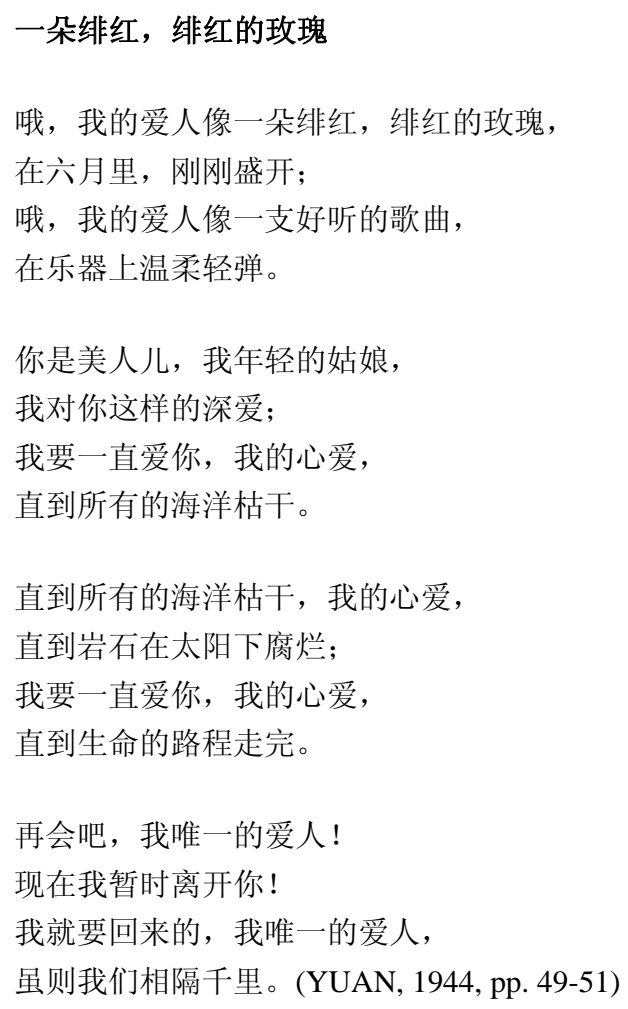

Yuan Shuipai's translation is rectified in form. The line length is almost the same as that of Burns'. The rhythm is good and the rhyme scheme sounds beautiful. The rhyme schemes of the four stanzas are respectively 
abcd (Burns’ being abcb), abbc (Burns’ being abcb), abab (Burns' being abab), abab (Burns' being abab).

The language he used is modern Baihua (non-archaic) Chinese, equal to the modern nature of Burns' language. (The sparse archaic English words and Scottish dialects cannot obliterate the modern nature of Burns' language as a whole.) Yuan Shuipai's translation is quite faithful, almost word-to-word. But some words he used are somewhat stiff, not popular with the masses, for example “绯红” for “red”, “我的心爱” for “my dear” and “腐烂” for “melt”.

The language is mainly colloquial, the same as the source text, for example, “你是美人儿” for “as fair art thou”. Burns' poem as a whole is colloquial and is a song itself. The rhythm of Yuan Shuipai is close to that of Burns'.

The tone in the translation is very sincere, conveying the meaning of the source text. Yuan Shuipai did not add his own ideas.

The translation is so faithful to the source text that he even translated the article "a" into Chinese as " 朵”. This is well done because in Chinese, the feeling “一朵红玫瑰” (a red rose) and “红玫瑰” (red rose) convey are not the same.

Yuan Shuipai adopted foreignization strategy completely. He retained the original style of Burns'. If one compares the source text and the target text, one may feel that Burns is the same in the Chinese version as it is in his own poem. Even the style of sentence pattern is retained, for example, “哦, 我的爱人像一朵绯红, 绯红 的玫瑰” for “O, my luve is like a red, red rose”. There is not even a slight change here. The other lines are almost the same as this.

This is a good Chinese version rendered by a young poet and translator (before he was 28). He retained the poetic culture of Burns' faithfully.

After 1919, with the implementation of the new culture and literary revolution, the call for using modern Baihua (non-archaic) language was gradually accepted by the masses. Yuan Shuipai, as a poet and active advocator of modern Chinese, knew well that literature should serve the broad masses and should be understood by the people. So he gave up using archaic Chinese and adopted the foreignization strategy to enrich the Chinese language. Therefore his translation is faithful and equivalent, and lyrical, identical to the purpose of the original poem. But some vitality is lost in his use of some unpopular diction like “绯红”. This shows that the change of language was still in a transitional period.

\section{Wang Zuoliang: The Third Person to Translate “A Red, Red Rose” in More Popular Modern Chinese}

Wang Zuoliang (1916-1995), a native of Zhejiang, a poet, translator, professor and expert on English literature.

A graduate of Tsinghua University, he became a teacher in the same university. In 1946, he returned to Beijing. In 1947, he went to Oxford University to study English literature. After returning from UK in 1949, he was assigned to work in Beijing Institute of Foreign Languages (the present Beijing Foreign Studies University) where he was a teacher and then a dean until he became the vice-president of the university.

His first book of Burns' poetry Selected Poems of Robert Burns was published in 1959 to memorize Burns' 200th anniversary by the People’s Literature Press. It contained “A Red, Red Rose”.

In 1986, his book Selected Poems of Scotland including 28 poems of Burns was published by Hunan People’s Press. 
In 1980 and 1985, his enlarged edition of Selected Poems of Robert Burns was published by Foreign Literature Press, which is another name of The People's Literature Press.

In 1980, his book A Selection of British Poems Translated into Chinese containing 11 of Burns' poems was published by Foreign Language Teaching and Research Press.

In 1987, his pocket book Love and Freedom was published by the People's Literature Press.

In 1998, his enlarged edition of Selected Poems of Robert Burns was published again by the People's Literature Press.

In 2012, the final enlarged edition of Selected Poems of Robert Burns consisting altogether of 45 poems of Burns was published by Foreign Language Teaching and Research Press.

In 2013, Love Is a Red, Red Rose including 18 of Burns' poems was published by Foreign Language Teaching and Research Press.

All the above-mentioned books contained "A Red, Red Rose".

Here is Wang Zuoliang’s translation of Burns' “A Red, Red Rose”:

一朵红红的玫瑰

啊, 我的爱人像朵红红的玫瑰,

六月里迎风初开,

啊, 我的爱人像一曲甜蜜的歌,

唱得合拍又柔和。

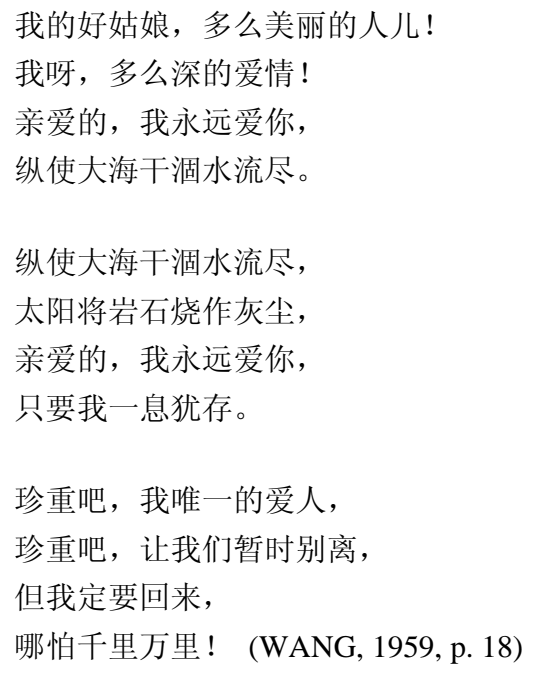

Wang Zuoliang's translation is rectified and beautiful in form. The line length is almost the same as that of Burns'. The rhythm is good with good sound group and the rhyme scheme varied from that of the source text. The rhyme scheme of the four stanzas are respectively abcc (Burns' being abcb), abcd (Burns' being abcb), aaba (Burns' being abab), abcb (Burns' being abab). In the arrangement of rhyme scheme he preferred to choose being natural and appropriate. I believe if he sought to keep the rhyme, he could rhyme the end words easily.

In his translation, Wang Zuoliang used modern Baihua (non-archaic) Chinese, equal to the modern nature 
of Burns' language. His translation of words is quite faithful, almost word-to-word. The translation of some words added more vivacity to the source text, for example, “六月里迎风初开” (That's newly sprung in June) and “只要我一息犹存” (While the sands o' life shall run). “迎风”, meaning “against the wind”, was added to "That's newly sprung in June" to make the rose more lively and "While the sands o' life shall run" was functionally and faithfully transformed into “As long as I breathe” (只要我一息犹存). He did not add his own idea while translating Burns but he wonderfully and convincingly domesticated the line "While the sands o' life shall run” wonderfully.

The language is mainly colloquial, the same as the source text, for example, “我的好姑娘, 多么美丽的人 儿! / 我呀, 多么深的爱情! ” (As fair art thou, my bonnie lass, / So deep in love am I). Burns’ poem itself is colloquial and is a popular song. The rhythm Wang Zuoliang used is close to that of Burns'.

The tone in his translation is very sincere, lyrical, and passionate, conveying effectively the meaning of the source text.

His translation is so faithful to the source text in terms of content that he retained the original beauty of meaning in his translation.

The strategy he adopted is foreignization. He retained the original style of Burns'. If one compares the source text and his translation, one may feel that Burns is the same in the Chinese version as it is in his own poem. Burns in the translation is still the Burns in his own poem. Even the style of the sentence pattern is retained, for example, “啊, 我的爱人像红红的玫瑰” for “O, my luve is like a red, red rose”. The word “啊” he used is more lyrical than “哦” used earlier by another translator and can convey the original meaning more truly. There is not even a slight change here. The other lines are almost the same.

In comparison with the translation of Yuan Shuipai, Wang Zuoliang's version is more colloquial, much easier to be understood, smoother, and livelier. The meaning, the artistic conception, the imagery, the line lengths, the rhythm, and rhyme are all retained. His translation did not harm the culture of the source text. The Chinese version can more easily arouse the passion of the readers and listeners in China as the English version did in UK. So it is more popular with the people.

Wang Zuoliang used the language that the people then loved to see and hear. It accorded with the task assigned to modern poetry which required that poetry translation should also be of political use, combative function, and instructional nature. Times required poets and translators to use pure language of the people to answer the call of the editorial by The People's Daily in 1951 to use pure and healthy language and avoid using formulated words. He attached importance to using the modern language which could be understood by people to meet the campaign of new folk songs. So his translation is colloquial and lyrical, in accordance with the aesthetic requirement of the new Chinese poetry to give access for people to feel its visual beauty and audial beauty.

\section{Yuan Kejia: The Fourth Person to Translate “A Red, Red Rose” Adding Beauty to the New Folk Poetry}

Though a teacher for a short period, Yuan Kejia (1921-2008) was mainly a poet, critic and translator. He took the lead in translating western modernistic poetry into Chinese and advocated writing new Chinese poetry. After 1949, he took part in translating The Selected Works of Mao Zedong. He had clear motive in introducing modern Chinese poetry to the West. In the early 1980s, he went to the United States to teach new poetry of China. 
His poetry translation is unique. His motive and purpose to absorb what is good from foreign poetry and to inspire Chinese new poetry to benefit the country's cultural construction can be clearly seen. For example, his translation of Burns was closely related to history, his experience of working in the countryside in 1950s and the need to create poems for common people. His translation of modernistic poetry was closely related to China's opening policy in the 1980s when people were eager to exchange ideas with the west.

He advocated that appropriateness should be mastered and form can be somewhat sacrificed for the sake of smoothness. One can see this clearly in his translation of Burns' poems.

He had his own idea of how to translate poetry. For example, he called on translators to avoid two things. The first is to avoid the vague generalization of language of merely translating the surface meaning of the source text without considering the general features of poetry and the personal language characteristics of a poet thus losing the real nature of the source text and failing to convey the spirit of the source text. The second is to avoid translating foreign poems into ancient forms of Chinese poetry and folk songs.

His greatest contribution to English literature is his translation of Burns' poems.

In 1959, his translation of Burns' poems entitled Selected Poems Robert Burns was published by the New Literature and Art Press in Shanghai to memorize Burns' 200th anniversary.

In 1981, his book Selected Poems Robert Burns was republished by Shanghai Literature and Art Press, the former New Literature and Art Press.

In 1986, it was published again by Shanghai Literature and Art Press.

In 1996, his book Selected Poems of Burns was published by Hunan Literature and Art Press.

In 2008, his last work My Luve Is Like a Red, Red Rose-the Best poems of Burns (illustrated edition) consisting of 91 poems was published again, this time by the People' Literature Press. This is his last words in his life.

Here is Yuan Kejia’s translation of Burns' "A Red, Red Rose”:

\section{一朵红红的玫瑰}

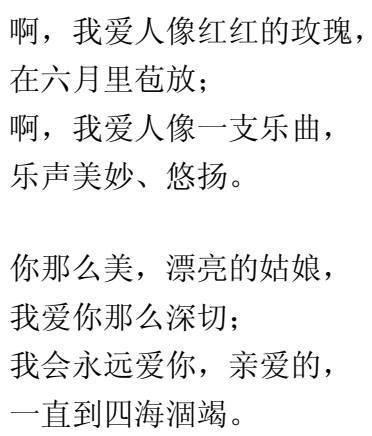


我会回来的, 我的爱人,

即使万里相隔！ (YUAN, 1959, pp. 192-193)

His translation is rectified in form and beautiful in sound. The line length is almost the same as that of Burns'. The rhythm in his translation is close to that of Burns. The pauses are quite natural, convenient for change of breath. It is remarkable that the rhyme scheme is exactly the same as that of the source text. The rhyme schemes of the four stanzas are respectively abcb (Burns' being abcb), abcb (Burns' being abcb), abab (Burns' being abab), abab (Burns' being abab). Yuan Kejia is the only translator who reproduced Burns' rhyme scheme with not any variation in the 20th century.

The language he used is modern Baihua (non-archaic) Chinese. He is good at grasping the gist, interpreting the main idea, using flexible sentence patterns, applying ingenious diction poetic or colloquial, never translating slavishly.

His translation conveys vividly the spirit of Burns' original poem which is very lyrical and passionate in it. He translated Burns' poems with identical language and style in order to absorb it, also in accordance with his purpose of enriching the Chinese folk songs. He kept faithful equivalence with the original words, almost translating them word by word, identical with the source text and the poet’s feeling, for example, “啊, 我爱人 像红红的玫瑰” for “O, my luve is like a red, red rose”. Besides, his frequent use of the phrases such as “...吧” and “...的” is positioned in the same way as Burns did. So he absolutely and faithfully retained the original beauty of meaning in the source text.

Yuan Kejia adopted the foreignization strategy completely and justifiably. He even retained the sentence patterns similar to those used in the source text. With sensitiveness of a poet, he reproduced Burns' meaning and style, realizing the functional equivalence, for example, “啊, 我爱人像一支乐曲, / 乐声美妙、悠扬。” If the original lines are translated literally, it should be “啊, 我的爱人像一支乐曲, / 她被甜蜜地吹奏合曲 调”. One can see that he just used the main idea, used his own rhythm and wording for the sake of smoothness and rhyme. On the basis of foreignization in form, there is some domestication in content by saying “乐声美妙、 悠扬。” which seem to be spoken by Burns without any traces.

In comparison with that of earlier translators, Yuan Kejia's version is more colloquial, but more lyrical, more concise, more harmonious, and more musical. The meaning, the artistic conception, the imagery, the line lengths, the rhythm, and rhyme are all retained. The Chinese version can more easily arouse the passion of the readers and listeners. So it is more popular with the people.

As done by Wang Zuoliang, Yuan Kejia used the language of the common people by answering the call of the editorial by The People's Daily in 1951 to use pure and healthy language and avoid using formulated words which also required that poetry translation should have political significance, combative function, and instructional nature. It is Yuan Kejia's life-long pursuit to enrich the Chinese folk songs by learning from foreign poetry. So his translation is in accordance with the aesthetic requirement of the Chinese new poetry to give access for people to feel its visual beauty and audial beauty.

\section{Guo Moruo: A Person Whose Translation of Burns” “A Red, Red Rose” Was Published Posthumously}

Guo Moruo (1892-1978) was a genius, a poet, scholar, historian, litterateur, scholar on ancient word writing, social activist, playwright, revolutionary and high-ranking official (a state leader). He was extremely 
talented, learned, and versatile.

In Japan he studied medicine when young. But he was more influenced by philosophers and poets. He later shifted to study literature and abandoned the traditional bondage and started a new fashion of poetry by to meet the new culture and literature revolution advocated in the May Forth Movement in 1919. He was a banner of progressive literature.

The Complete Works of Guo Moruo consists of 38 volumes!

In his whole life, he translated 238 foreign poems (see Zhang Yue’s statistics). Among these, he translated 61 English poems.

His Manuscript of a Translation of English Poems was published in 1981, three years after his death, by Shanghai Translation Press, though he started to translate them beginning from 1969.

The three remarkable features of Guo Moruo's translation are as follows: 1. translating poetry into poetry; 2. translating poetry as a poet does; 3. infusing the translator's own charm and personality into his translation.

The main poetic forms Guo Moruo used in his translation are four: 1. in Baihua form (non-archaic) Chinese; 2. in ancient Chinese and metric form; 3. in both ancient Chinese and modern Baihua (non-archaic) language; 4. in free verse.

Guo Moruo's first principle of translation (Translating poetry into poetry) can be further explained as follows: 1 . The number of lines should be the same as in the source text; 2 . The translation must use rhyme; 3 . The form should be orderly. The form can be in classic style or in modern style.

Guo Moruo's second principle of translation (Translating poetry with translator's charm and personality) can be further explained as follows: 1. Meaning is more important than form. The soul and spirit of the source text must be kept; 2 . The translation should not be rigid. Flexibility is required. The artistic conception of the source text is very important. To retain it and transfer it easily, one can translate the original words which can also be reworked and reorganized. This is closely connected with his identity as a poet and his romantic sentiments.

Guo Moruo's third principle of translation (Creative translation) may contain the following ideas: 1 . On the basis of grasping the artistic conception, rewriting is allowed; 2. On the basis of grasping the artistic conception, creative translation is permitted; 3 . Translation is an artistic creation.

In his translation of Burns' "A Red, Red Rose”, the creative element is evident. Here is his translation of Burns' “A Red, Red Rose”:

红玫瑰

吾爱吾爱玫瑰红,

六月初开韵晓风;

吾爱吾爱如管弦,

其声悠扬而玲珑。

吾爱吾爱美而殊,

我心爱你永不渝,

我心爱你永不渝,

直到四海海水枯; 


\author{
直到四海海水枯, \\ 岩石融化变成泥, \\ 只要我还有口气, \\ 我心爱你永不渝。 \\ 暂时告别我心肝, \\ 请你不要把心耽! \\ 纵使相隔十万里, \\ 踏穿地皮也要还。(GUO, 1981, p. 27)
}

It is very interesting that Guo Moruo, a banner of new literature and Baihua Chinese campaign, used the ancient classical form of seven-character-line quatrain for this poem. This translation is very rectified and orderly in form and beautiful in sound. It even sounds exaggerated in some places.

The rhythm in his translation is good and expected. The rhyme scheme is flexible. The rhyme schemes of the four stanzas are respectively aaba (Burns’ being abcb), abba (Burns’ being abcb), abbb (Burns' being abab), aaba (Burns’ being abab).

At first look, the language is ancient classical Chinese, for example, “吾爱吾爱”, and some words are very literary, such as “韵晓风” (rhyme with dawn breeze) and “不渝” (do not change) , but actually this poem is a combination of ancient classical Chinese and modern Baihua Chinese, for example, “岩石融化变成泥” (the rock melts into mud) and “暂时告别我心肝” (say goodbye to my darling for a while). There is a feeling that many modern Baihua (non-archaic) Chinese words are put in the framework of ancient classic Chinese.

Though in the framework of ancient classical Chinese, it is still colloquial, for example, “只要我还有口气” (as long as I have breath) and “请你不要把心耽！” (you please don’t worry).

The tone in the translation sounds exaggerated and funny sometimes, for example, “踏穿地皮也要还” (I’ll return even when I tramp through the earth’s surface) and “岩石融化变成泥” (the rock melts into mud). The disposition of the translator himself is clearly shown here: romantic and lofty in sentiment.

He attached great importance to artistic conception and mastered the spirit of the source text. So he translated it in a creative way, adding his own poetic charm and ideology to the source text. In this respect he was not at all faithful to the source text.

He adopted the domestication strategy completely by localizing and nationalizing “A Red, Red Rose” into Chinese culture. But gone was Burns' style and poetic culture. Sometimes the change is radical, for example, the first line's change is so dramatic. The theme is "my love" and the rheme is "is like a red, red rose". But he changed the first line into "I love I love the rose red”. Gone is the simile "like a red, red rose”. Even if “吾” can be used as “my”, his sentence still needs reconsideration because “吾爱吾爱玫瑰红” can be translated back as "My love, my love, the rose red". This does not make sense. Too much subjectivity is displayed. So his translation strategy and principles caused the change of meaning.

Generally speaking, Guo Moruo’s “A Red, Red Rose” is a very good poem in terms of poetic creation. The form is orderly and rectified. The rhythm is good and the rhyme is beautiful. But in terms of language and passion, it is much different from that of Burns. The domestication strategy and the creative translation somewhat deprived Burns of his poetic culture and style.

Guo Moruo displayed his mastery of classic learning by using ancient poetic form. As a great poet versed in both ancient classical Chinese and modern Baihua Chinese, and as a historian and expert on ancient word 
writing, he fully demonstrated his classical awareness that flowed in his veins. So it is quite normal that he liked the ancient classical form. But it is more normal for him to use modern Baihua language, because he must use the modern language since he was official on different posts. This poem is a modern expression of his classical form. So it is much easier than Su Manshu's to be understood. Guo Moruo mixed classical Chinese and modern Chinese in this translation for the purpose of making it easy to understand and at the same time to remind readers of the classical tradition, glorious culture and expressive beauty.

\section{Zhou Yi’nai: The First Non-literary Major to Translate “A Red, Red Rose” in Five-Character-Line Quatrain}

It is quite delightful that Zhou Yi'nai (1915-1996), a native of Anhui and a major of mechatronics from Wuhan University translated this poem very nicely. He went to UK to study in 1947 and returned to China in 1951. He published a collection of British and American poems entitled 自由之歌 (Songs of Freedom) which was published by China Translation \& Publishing Corporation in 1999. The book contains 161 pages. In this book, he only translated two of Burns' poems, one of them being “A Red, Red Rose”. He used classical poetic form and ancient Chinese. Here is Zhou Yi'nai's translation of Burns' “A Red, Red Rose”:

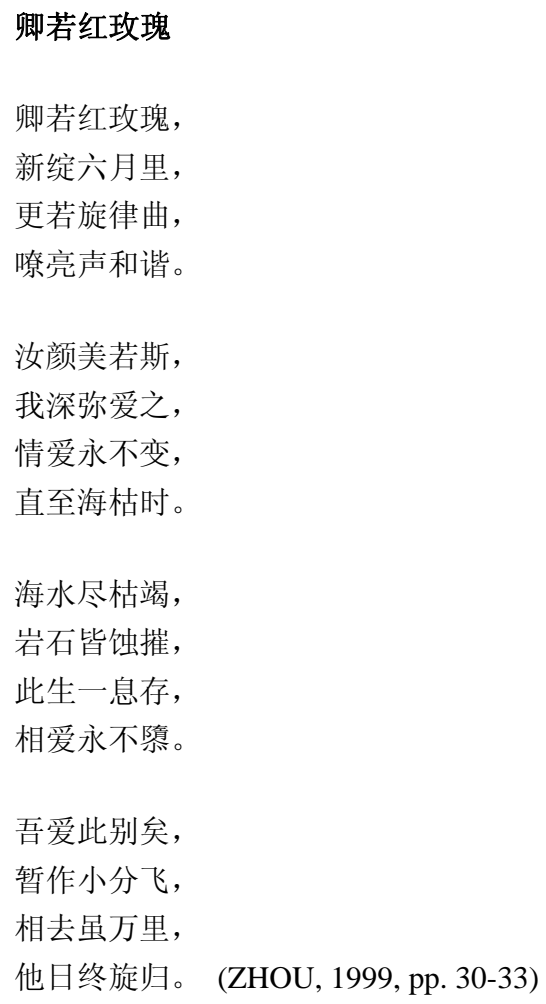

It is quite delighting that he translated this poem so nicely and neatly. He used the classical form of five-character-line quatrain. It is very rectified and orderly in form and beautiful in sound.

The rhythm in the translation is good and the rhyme scheme is flexible. The rhyme schemes of the four stanzas are respectively abbc (Burns' being abcb), aaba (Burns' being abcb), abcb (Burns' being abab), abab (Burns' being abab). 
In almost the whole poem he used words full of classic beauty and elegant taste while retaining the similes such as “卿若红玫瑰” (You are like a red rose) and “更若旋律曲” (You are more like a melody). The original meaning is retained in concise words. The other words also reveal the charm of classical poetry. The language is formal and literary.

The tone in the translation is appropriate and serious with no exaggeration, with no loss of meaning. He is faithful to the source text without mistranslation.

By adopting the domestication strategy completely, Zhou Yi'nai localized and nationalized Burns' poem into Chinese culture. But gone was Burns' style and poetic culture. Gone was the farmer Burns. Burns became an ancient Chinese litterateur.

In terms of translation, this is very good work. Though the form is changed, the meaning is retained. So he was very serious and had very good skills of translation. Though he majored the engineering, his level of Chinese was terrific. He was not a poet, but surpassed a poet.

\section{Li Zhengshuan (1963- ): A Translator Who Tries His Best to Reproduce Burns' Style}

Normally, the contemporary Chinese mainly use pure Baihua Chinese because the Baihua Chinese is the language required to be used. More translators try to use modern Chinese in their translation of poetry written in modern English. Li Zhengshuan is one of such translators.

$\mathrm{Li}$ Zhengshuan is a professor teaching English and American poetry, poetry translator doing English-Chinese translation and Chinese-English translation, and a person who writes poems in Chinese and English. He has translated many English and American poems into Chinese and many Chinese poems into English. He has translated almost two hundred poems of Burns and is to publish two books of Burns' poems translated into Chinese.

He adheres to the following principles of translation: 1 . translating poetry into poetry; 2 . using rhyme whenever and wherever possible; giving up rhyme so as not to harm the meaning; 3 . pursuing faithful equivalence in understanding, culture transfer and style reproduction.

Here is Li Zhengshuan's translation of Burns' "A Red, Red Rose”:

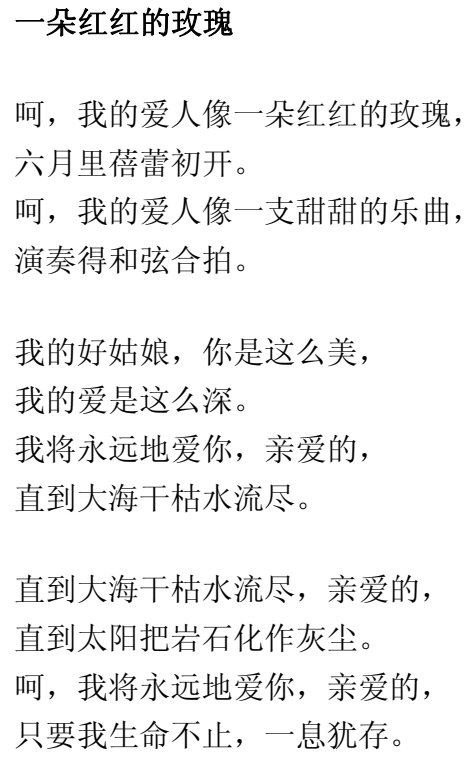




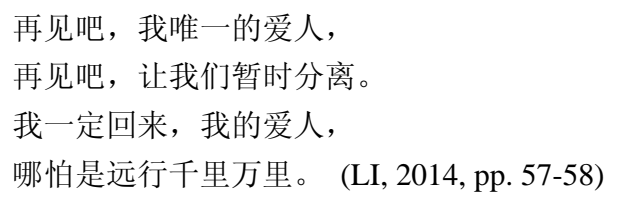

Li Zhengshuan's translation of this poem is rectified and beautiful in form and sound. The poetic lines are faithfully conveyed in Chinese. The line length is the same as that of Burns'. The rhythm is musical like a song and the rhyme is harmonious and resounding, retaining that of Burns. Burns' poetic culture is retained and transferred to China.

The rhyme of the whole poem in the translation is beautiful and the rhyme schemes are exactly the same as that of the source text. The rhyme schemes of the four stanzas are respectively abcb (Burns' being abcb), abcb (Burns' being abcb), abab (Burns' being abab), abab (Burns' being abab). He is the only translator who unmistakably reproduced Burns' rhyme scheme with not any slight variation in the 21st century.

The language in his translation is modern Baihua (non-archaic) Chinese from beginning to the end, identical to that of the source text. The number of words is also transferred as if being photocopied. The image of a burning Burns can be found in this translation. This poem is lyrical and passionate like Burns singing in person in Chinese.

The tone is very sincere and appropriate, conveying the tone of the source text and the meaning of the source text. The translation is very lyrical and passionate.

The translation is absolutely faithful to the source text in terms of contents, form, tone, feeling, style, and rhythm, with not any mistranslation. Equivalence can be found in the number of lines, the length of each line, the rhyme scheme, artistic conception and images. He even translated the article "a" into a quantity word (the first and the third lines) and repeated the words originally repeated in the source text, for example, “一朵红红 的玫瑰” for “a red, red rose”. This repetition cannot be omitted. The repetition has its own meaning in the source text and the feeling it conveys must be reproduced.

Li Zhengshuan adopted the foreignization strategy agreeably and expressively. He used almost literal translation, faithful to the style of the source text, wishing that Burns be happy to see his own image in the translation. The souls of the poet and that of the translator are intermingled. He did not try to surpass Burns, but translated his poems with the feeling of the poet.

\section{Some Experiments by New Translators}

Surfing on the Internet, one can find some recent experiments on translating the poem "A Red, Red Rose". One translator named himself as "Naughty Boy Xiaoniu". He used the verse style of The Book of Songs. This is an interesting trial, beautiful and good enough, with orderly form and sound. All the metaphors are retained. But the words used are too few to convey all the meaning of the source text.

Another translator called herself M. Z. Rainleaf (Rain Beating on Duckweed). She is the first person that dares to challenge early translators by translating “Luve” as “恋人”. She is quite right in translating in this way.

Yet another translator called herself "Xuexue Small Chive”. She rendered a more interesting version by translating “a” into “一瓣”. Her daring spirit is praiseworthy. But there is some room to be desired in her translation. First, the modern poetic form is not beautiful enough. Second, some lines are too long. Third, the sound is somewhat rough and rhyme is also somewhat loose. Fourth, sometimes there is misunderstanding. For 
example, she should not have translated “a” into “一瓣”. There are some other places of misunderstanding and mistranslation. The language is rather informal, distant from being poetic. If the translator knew something more about English poetry, her translation could have become better.

However, we are also quite delighted to have found two more presentable versions. One is done by Bi Hong who displayed his solid basis of Chinese ancient civilization which can be seen in the following version entitled “我爱”: “我爱如玫瑰, / 六月红蕾姣。 / 我爱如乐曲, / 妙奏声衰衰。 || 爱卿无限深, / 如 卿绝世妍。 / 直至海水枯, / 此爱永绵绵。 || 直至海水枯, / 炎阳熔岩石。 / 但教一息存, / 爱 卿无终极。|| 离别只暂时, / 善保千金躯。 / 终当复归来, / 万里度若飞。” This translation is neat in rectified form, beautiful to look at and nice to hear. The images are also well reproduced. The tone is appropriate and solemn. The translation is faithful to the source text in terms of contents, though the original poetic style is lost.

The other version was rendered by a person who called himself "Plum Chanting and Broadcasting". The title of this translation is “爱若红玫”. The translation goes like this: “六月红玫枝头俏， / 似卿容颜添娇娆; / 弦上弹拨乐曲美, / 如卿身段格外自。 || 偏赏少女婀娜姿, / 独爱美人日夜思; / 恋卿日浓终不 悔, / 海枯有时爱无期。 || 海枯有时爱无期, / 石烂无常情有寄; / 爱卿之意绝无改, / 斗转星移 漏沙粒。 || 暂且别卿于今朝, / 难舍难分溢言表; / 不日定当重相见, / 纵使离卿万里遥。” This translation is acceptable though there is room to be desired in that some lines are mistranslated, some lines are half-created and some lines deviate from the original meaning. But generally speaking this version is readable and presentable.

\section{Conclusion}

Burns' “A Red, Red Rose” has been thus loved by the Chinese people, famous and ordinary, which proves the universality of thought and feeling expressed in this poem. It appeals to all people whatever their nationality is. The rose is no longer merely a plant. It has become a symbol of love, an embodiment of feeling and an outlet of passion. Nobody but a genius could transform an ordinary flower among many more beautiful flowers into such a wonderful expression of human sentiment. The Chinese people, like people worldwide, appreciated this poem so fully that generation after generation of scholars have tried to present it to more people with more beauty and passion. One of the reasons for this is that Burns wrote for ordinary people and sang praise of the commons which in turn won him the name of a poet of the laboring people.

\section{References}

GUO, M. R. (1981). 英诗译稿 (Manuscript of a translation of English poems). Shanghai: Shanghai Translation Press. LI, Z. S. (2004/2014). 英美诗歌教程 (A course of English and American poetry). Beijing: Tsinghua University Press. LIU, Y. Z. (Ed.). (2007). 苏曼殊文集 (Works of Su Manshu). Beijing: Contemporary China Press. LU, X. (1980). 鲁迅全集 (第一卷) (The complete works of Lu Xun (Vol. I)). Beijing: The People’s Literature Press. WANG, Z. L. (1959). 彭斯诗选 (Selected poems of Robert Burns). Beijing: The People’s Literature Press. YUAN, K. J. (1959). 彭斯诗选 (Selected poems Robert Burns). Shanghai: New Literature and Art Press. YUAN, S. P. (1944). 我的心儿呀在高原 (My heart’s in the highlands). Chongqing: Xinqun Press. ZHOU, Y. N. (1999). 自由之歌 (Songs of freedom). Beijing: China Translation \& Publishing Corporation. 郭沫若 (Guo Moruo). (n.d.). Retrieved from http://baike.sogou.com/v40882.htm

鲁迅 (Lu Xun). (n.d.). Retrieved from http://baike.sogou.com/v5736.htm 苏曼殊 (Su Manshu). (n.d.). Retrieved from http://baike.sogou.com/v41154.htm 
王佐良 (Wang Zuoliang). (n.d.). Retrieved from http://baike.sogou.com/v41210.htm 叶遥 (Ye Yao). (n.d.). 怀念袁水拍. Retrieved from http://www.cnki.com.cn/Article/CJFDTotal-XWXS200203029.htm 袁可嘉 (Yuan Kejia). (n.d.). Retrieved from http://baike.sogou.com/v42377.htm 袁水拍 (Yuan Shuipai). (n.d.). Retrieved from http://baike.sogou.com/v8094215.htm 周宜乃 (Zhou Yi’nai). (n.d.). Retrieved from http://product.dangdang.com/719026.html 